\title{
Contamination and Ecological Risk Assessment of Heavy Metals in Surface Soils of Esfarayen City, Iran
}

\author{
Anoushiravan Mohseni-Bandpei, ${ }^{1}$ Seyed Davoud Ashrafi, ${ }^{2,3}$ Hossein Kamani,,${ }^{4,}$ and Ali Paseban ${ }^{1,5,}$ \\ ${ }^{1}$ Department of Environmental Health Engineering, School of Public Health, Shahid Beheshti University of Medical Sciences, Tehran, Iran \\ ${ }^{2}$ School of Health, Guilan University of Medical Sciences, Rasht, Iran \\ ${ }^{3}$ Research Center of Health and Environment, Guilan University of Medical Sciences, Rasht, Iran \\ ${ }^{4}$ Health Promotion Research Center, Zahedan University of Medical Sciences, Zahedan, Iran \\ ${ }^{5}$ Department of Environmental Health Engineering, School of Public Health, North Khorasan University of Medical Sciences, Bojnurd, Iran \\ "Corresponding authors: Ali Paseban, Department of Environmental Health Engineering, School of Public Health, Shahid Beheshti University of Medical Sciences, Tehran, Iran. \\ Tel: +98-9151867833, E-mail: alipaseban@gmail.com; Hossein Kamani, Health Promotion Research Center, Zahedan University of Medical Sciences, Zahedan, Iran. Tel: \\ +98-9155412919, E-mail: hossein_kamani@yahoo.com
}

Received 2016 June 30; Revised 2016 August 31; Accepted 2016 September 16.

\begin{abstract}
Background: The urban soil characteristic is very important since numerous people live in cities nowadays. In recent decades, heavy metals enter into the urban environment due to the urbanization and different activities in cities. These metal contaminations can pose serious threats on community health. Contamination factor is a suitable tool for ecological geochemistry assessment.

objectives: The current study aimed to determine the distribution and concentration of heavy metals ( $\mathrm{Ni}, \mathrm{Pb}, \mathrm{Zn}, \mathrm{Cd}, \mathrm{Cu}$ and $\mathrm{Cr}$ ) in soil from urban soils, assess the pollution level and potential ecological risk of heavy metals.

Methods: Forty surface soil samples from different areas with different functions in five districts of Esfarayen, Iran, were collected and transferred to laboratory, after drying the samples at laboratory temperature, they were analysed to measure $\mathrm{Ni}, \mathrm{Pb}, \mathrm{Zn}, \mathrm{Cd}, \mathrm{Cu}$ and $\mathrm{Cr}$ using inductively coupled plasma optical emission spectrometry. Results: The results showed the mean contents of $\mathrm{Cd}, \mathrm{Cu}, \mathrm{Cr}, \mathrm{Ni}, \mathrm{Pb}$ and $\mathrm{Zn}$ in soil of Esfarayen were 0.21, 33.27, 39.9, 32.3, $25.2 \mathrm{and} 106 \mathrm{mg} / \mathrm{kg}$, respectively, which were more than the natural background content. The potential ecological risk index ranged from 21.0 to 651 with a mean value of 159 .

Conclusions: Among different functional areas, the industrial areas had the maximum metal concentrations. According to the potential ecological risk indices, industrial region and city squares in Esfarayen have serious metal contamination and belong to the considerable pollution level. The results of the current study are very important for managers who define development strategies in cities and are also good to source pollution reduction.
\end{abstract}

Keywords: Heavy Metal, Contamination, Ecological Risk Assessment, Esfarayen City

\section{Background}

Contamination of urban surface soils with heavy metals is one of the worrying problems owing to their extensive causes, resistant to biodegradation, toxic and accumulative properties. Heavy metals and other pollutants in urban surface soils are usually originated from different sources of industrial activities, fossil fuel combustion, transportation and waste disposal $(1,2)$. The severe accumulation of rare metals in the urban surface soils have harmful effects on soil ecosystem, citizens' health and cause other environmental problems.

Various literatures documented on heavy metal contaminations in various surface soils around the world (2). Low level of some heavy metals such as cadmium and lead are dangerous to human health (3). Generally, heavy metals can cause different health problems in humans. For example, cadmium accumulation in human body causes malfunction of kidney, cancer and lead in body causes neurological disorders, anaemia and renal damage; and frequent presence of heavy metals in soil is reported as an indicator of the quality of the urban environment (4). Heavy metals do not decompose in the environment and finally, through breathing and food chain, accumulate in tissues. They can cause injuries in the nervous systems and inter- nal organs (5). These metals can increase cardiovascular diseases, reproductive problems and different cancers (6, 7 ). In recent years, the presence of heavy metals in surface soil is one of the main concerns of environmentalists and the evaluation of topsoil contamination in the populated areas is one of the major concerns related to the public health. In this regard, contamination factor $\left(\mathrm{C}_{\mathrm{f}}\right)$, potential ecological risk factor $\left(E_{r}\right)$ and potential ecological risk index (PER) are indices to evaluate the heavy metals contamination level. These indices simply show the level of contamination or enrichment in the soils, sediments and road dusts (8).

Esfarayan is one of the industrial areas in northeast Iran that was quickly industrialized and urbanized in recent decades. There are a lot of industrial activities; Esfarayen industrial complex, Esfarayen Lule Gostar company and other small industries and residential heating; heavy metals from the aforementioned activities threaten the environment and human health in this city. To the best of the authors' knowledge, there are not any studies regarding the heavy metals content in Esfarayen and their contamination level. Therefore, the current study aimed to determine the distribution and concentration of heavy metals ( $\mathrm{Ni}, \mathrm{Pb}, \mathrm{Zn}, \mathrm{Cd}, \mathrm{Cu}$ and $\mathrm{Cr}$ ) in soil from urban soils, assess the pollution level and potential ecological risk of 
heavy metals.

\section{Methods}

This evaluation was performed in Esfarayen, North Khorasan province, Iran. It is located on longitude $56^{\circ}$ $57^{\prime}-58^{\circ} 7^{\prime}$ and East and latitude $36^{\circ} 40^{\prime}-37^{\circ} 17^{\prime}$ North. It has an area of $5019 \mathrm{~km}^{2}$ with 156 thousand inhabitants. In this area, the average annual precipitation is $212 \mathrm{~mm}$ with a temperate mountain climate and an annual average temperature of $8-13^{\circ} \mathrm{C}$. The wind direction is from the North-West to South-East with the annual average speed of $4-6 \mathrm{~ms}^{-1}$. Forty surface soil samples ( 0 - 2 $\mathrm{cm}$ ) were collected from different major functional areas in five districts in September 2015. To collect composite samples, a few subsamples were randomly collected from each site and mixed to achieve one composite sample (9). Among 40 samples, numbers 4, 8, 5, 17 and 6 were from suburbs, industrial regions, urban parks, city squares and roadsides, agricultural regions and residential areas, respectively. The geographical coordinates of samples were recorded using a global positioning system (GPS). In order to determine the background heavy metal concentration in suburbs, sampling was carried out from one meter under ground level (10). The samples were collected from topsoil and then transferred to the laboratory in closed polyethylene bags. To prevent the loss of possible volatile metallic compounds, all samples were dried at lab temperature for 10 days and sieved to remove particles bigger than $2 \mathrm{~mm}$. One gram of each dried sample was digested according to the United States environmental protection agency (USEPA), method $3050 \mathrm{~B}$, using $\mathrm{HCl}, \mathrm{HNO} 3$ and $\mathrm{H}_{2} \mathrm{O}_{2}$ for the heavy metals analysis (11). The digested solution was cooled and filtered (pore size $0.45 \mu$ ). The concentrations of $\mathrm{Ni}, \mathrm{Pb}$, $\mathrm{Zn}, \mathrm{Cd}, \mathrm{Cu}$ and $\mathrm{Cr}$ were determined in the filtrated solution using inductively coupled plasma optical emission spectrometry (ICP-OES) (Spectro Arcos Model, Cleve, Germany).

\section{Results}

\subsection{Heavy Metals Concentration}

Table 1 presents the descriptive statistics of heavy metals contents of urban soils in the study. According to Table 1 , there was significant differences among different heavy metal contents. The concentrations of six heavy metals $(\mathrm{Cd}, \mathrm{Cr}, \mathrm{Cu}, \mathrm{Ni}, \mathrm{Pb}$ and $\mathrm{Zn}$ ) varied between $0.01-1,3.82-150$, $6.14-126,7.05-87.9,8.58-67.9$ and $23.2-338 \mathrm{mg} / \mathrm{kg}$, respectively. The mean concentrations were $0.21,33.27,39.9,32.3$, 25.2 and $106 \mathrm{mg} / \mathrm{kg}$, respectively. The average concentrations of the investigated metals in all sampling sites with all land uses were in the order of $\mathrm{Zn}>\mathrm{Cu}>\mathrm{Cr}>\mathrm{Ni}>\mathrm{Pb}>$ Cd.

The average concentrations of the investigated heavy metals, except $\mathrm{Cu}$, were lower than those of the soil standard of the Netherlands (target value), and the average concentrations of them were lower than the recommended guideline values (12). The mean concentrations of all metals were below the Canadian soil quality guidelines (13). Low heavy metal concentrations in some samples compared to the other standards indicated that these sites were not affected seriously and the effect of pollutant sources can be ignored while high heavy metal concentrations indicated that the pollutants seriously influenced the soil environment $(12,13)$. For some sampling sites, the concentrations of $\mathrm{Zn}$ were higher than those of the soil standard of the Netherlands (12), where $2.78 \%$ of samples were higher than those of the Dutch soil quality intervention value. It was found that $2.78 \%, 8.33 \%, 38.89 \%, 27.78 \%$ and $19.44 \%$ of the $\mathrm{Cd}, \mathrm{Cr}, \mathrm{Cu}, \mathrm{Ni}$ and $\mathrm{Zn}$ concentrations, respectively, were higher than those of the Dutch soil quality standard (target value) (12).

The concentrations of $\mathrm{Ni}, \mathrm{Pb}, \mathrm{Cd}, \mathrm{Zn}$ and $\mathrm{Cr}$ in various areas with different uses were higher than those of the corresponding natural background of heavy metals in the soil of Esfarayen (Figure 1). Heavy metal contents in the industrial areas were pretty higher than those of other functional areas in Esfarayen. In the current study, significant differences $(\mathrm{P}<0.05)$ were observed between different land uses. The main sources of emission of heavy metal in the investigated area were industrial activities including Esfarayen industrial complex and Luleh Gostar industrial Company. According to the previous study in Shenyang, $\mathrm{Pb}$ concentration varied in different functional areas with the order of industrial area $>$ commercial area $>$ residential area $>$ suburb (14), which was consistent with that of the present study. City squares and roadsides contained rather higher concentrations of heavy metals than residential areas. Main roadsides are usually under the influence of high traffic which causes emission of heavy metals into the environment.

Lu and Bai (15) stated that automobile exhausts are the main source of $\mathrm{Pb}$ and emission of other heavy metals into the roadside soils near the motorways. These sources of emission also increase human exposure to high levels of heavy metals (16).

Numerous studies have proved that the elevated concentration of $\mathrm{Cu}$ and $\mathrm{Zn}$ can be released to the urban environment from various parts of automobiles, especially break abrasion $(17,18)$. According to the above results, industrial and traffic activities were the main sources of emission of heavy metal into the environment of Esfarayen. Heavy metal concentrations in the urban park ar- 
Table 1. Descriptive Statistical Analysis of Heavy Metals Concentrations in the Urban Soils and Related Guideline Value

\begin{tabular}{|c|c|c|c|c|c|c|}
\hline Statistical Analysis & Cd & $\mathbf{C r}$ & $\mathbf{C u}$ & $\mathbf{N i}$ & $\mathbf{P b}$ & Zn \\
\hline Mean & 0.21 & 33.27 & 39.9 & 32.3 & 25.2 & 106 \\
\hline Std. Deviation & 0.22 & 37.1 & 33.3 & 23.1 & 15.2 & 74.1 \\
\hline Coefficient of variance (CV) & 104 & 111 & 83.9 & 71.5 & 62.4 & 70.2 \\
\hline Median & 0.13 & 13.5 & 26.9 & 23.6 & 19.3 & 83.8 \\
\hline Minimum & 0.01 & 3.82 & 6.14 & 7.05 & 8.58 & 23.2 \\
\hline Maximum & 1.00 & 150 & 126 & 87.9 & 67.9 & 338 \\
\hline Background value & 0.06 & 7.97 & 13.7 & 12.7 & 12.7 & 23.2 \\
\hline Canadian soil quality guidelines & 22.0 & 87.0 & 91.0 & 50.0 & 600 & 360 \\
\hline Dutch soil quality standard (target value) & 0.80 & 100 & 36.0 & 35.0 & 85.0 & 140 \\
\hline Dutch soil quality standard (intervention value) & 12.0 & 380 & 190 & 210 & 530 & 270 \\
\hline Sample which exceeded Canadian soil quality guidelines (\%) & 0.00 & 13.9 & 11.2 & 25.0 & 0.00 & 0.00 \\
\hline Sample which exceeded Dutch target value (\%) & 2.78 & 8.33 & 38.9 & 27.8 & 0.00 & 19.5 \\
\hline Sample which exceeded Dutch intervention value (\%) & 0.00 & 0.00 & 0.00 & 0.00 & 0.00 & 2.78 \\
\hline
\end{tabular}

eas were relatively lower than those of other functional areas in Esfarayen.

\subsection{Comparison With Other Studies}

The mean concentrations $\left(\mathrm{mg} \mathrm{kg}^{-1}\right)$ of heavy metals in urban soils of different cities worldwide are given in Table 2 . On the whole, the heavy metal concentrations in the present study were moderate compared to the reported results from other studies. The results of the study in China were similar to those of Beijing and Tianjin and they were also comparable to the results of less industrially developed cities such as Chongqing and Shenzhen. The results of the study were much lower than the reported results of large and industrialized cities such as Changsha, Tehran, Baoji, Istanbul, Nanjing and Xi'an. The average concentrations of $\mathrm{Cd}, \mathrm{Cu}, \mathrm{Pb}$ and $\mathrm{Zn}$ were fairly low compared to the reported concentrations in cities with large or old industrial activities such as Mexico City, Naples, Palermo, Seville and Turin. The average concentrations of $\mathrm{Cr}$ and $\mathrm{Ni}$ in soils of Esfarayen were comparable to those of the other studies, except for Turin and Mexico City. Concentration of $\mathrm{Pb}$ in the current study was lower than those of the other studies. Small amounts of $\mathrm{Pb}$ may display an advance of urban soil characteristics since the consumption of leaded gas was forbidden in Iran.

\subsection{Contamination Factor}

Contamination factors were computed according to the local background values of heavy metals in soils of Esfarayen using the following equation (Equation 1) (19).
$C_{f}=\frac{C_{\text {heavymetal }}}{C_{\text {background }}}$

where $\mathrm{C}_{\text {heavy metal }}$ is the measured concentration of a heavy metal in a sample and $\mathrm{C}_{\text {background }}$ is the mean concentration of the corresponding heavy metal in the local background samples.

Hakanson (20) defined four classes of $\mathrm{C}_{\mathrm{f}}$, five classes of $E_{r}$, and four classes of PER, as presented in Table 3. The $C_{f}$, varied considerably in various metals and various typical soils. The $\mathrm{C}_{\mathrm{f}}$ value varied from 0.17 to 17.4 with a mean value of 3.63 for Cd, 0.48 to 18.8 with a mean value of 4.18 for $\mathrm{Cr}$, 0.45 to 9.16 with a mean value of 2.90 for $\mathrm{Cu}, 0.56$ to 6.94 with a mean value of 2.55 for $\mathrm{Ni}, 0.61$ to 5.35 with a mean value of 1.96 for $\mathrm{Pb}$ and 1.00 to 14.6 with a mean value of 4.55 for $\mathrm{Zn}$. The results showed that $\mathrm{C}_{\mathrm{f}}$ mean for $\mathrm{Cd}, \mathrm{Cr}$ and $\mathrm{Zn}$ were within the considerable contaminated grade $\left(3 \leq \mathrm{C}_{\mathrm{f}}\right.$ $<6$ ) and mean of $\mathrm{C}_{\mathrm{f}}$ for $\mathrm{Cu}, \mathrm{Ni}$ and $\mathrm{Pb}$ were in moderate contaminated grade $\left(1 \leq \mathrm{C}_{\mathrm{f}}<3\right)$. For $\mathrm{Cd}$, $\mathrm{Cr}$ and $\mathrm{Zn}$ mean concentration in soil samples of industrial region sites showed high contamination, and for $\mathrm{Cd}, \mathrm{Cu}$ and $\mathrm{Pb}$ concentration in soil, urban park sites showed low contamination.

\subsection{Potential Ecological Risk Index}

Potential ecological risk index (PER) and ecological risk factor $\left(E_{r}\right)$ are useful techniques for environmental assessment, suggested by Hakanson (20). Responsibility and sensitivity of the biological community to the toxic substances can be illustrated by PER and $\mathrm{E}_{\mathrm{r}}$. PER also illustrates the potential ecological risk caused by the overall contamination. $E_{r}$ of each heavy metal and PER for heavy metals are calcu- 
Cd

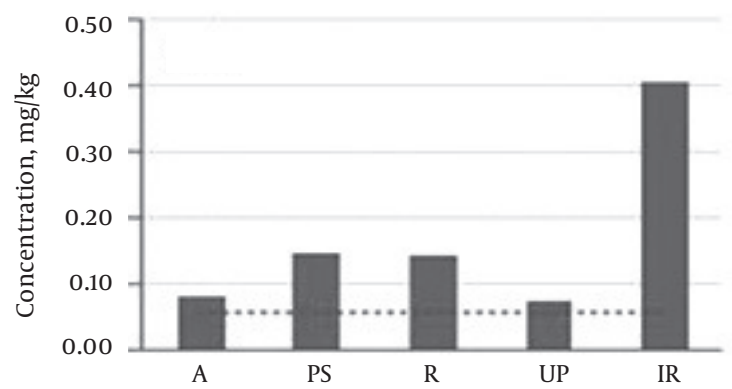

$\mathrm{Cu}$

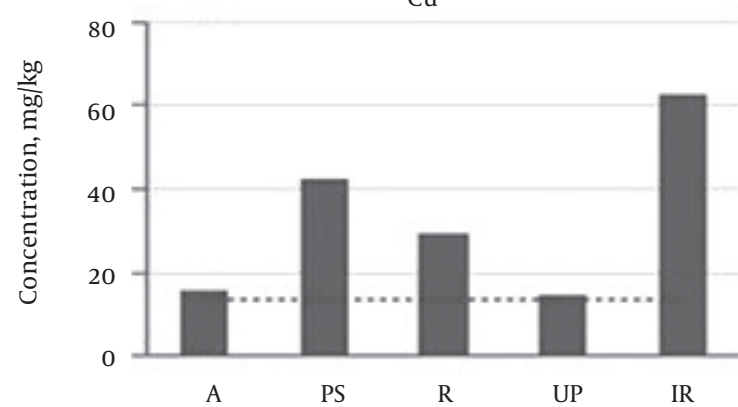

$\mathrm{Pb}$

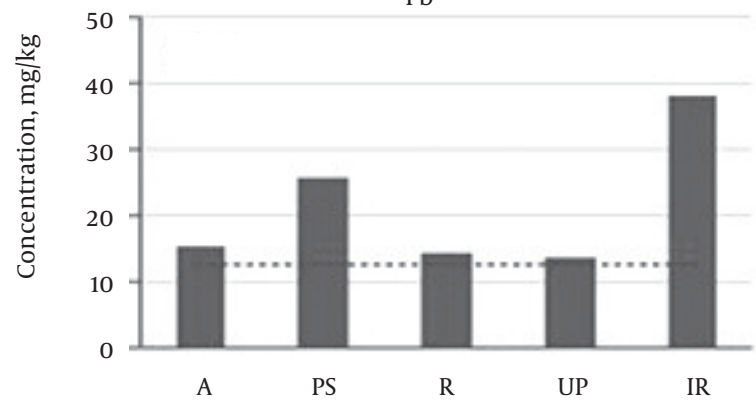

$\mathrm{Cr}$

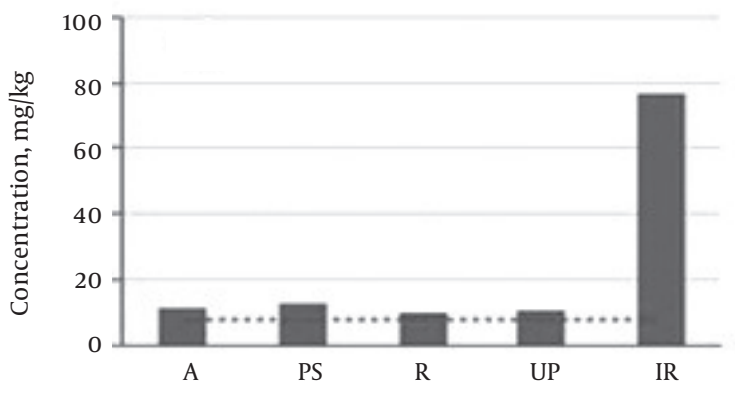

$\mathrm{Ni}$

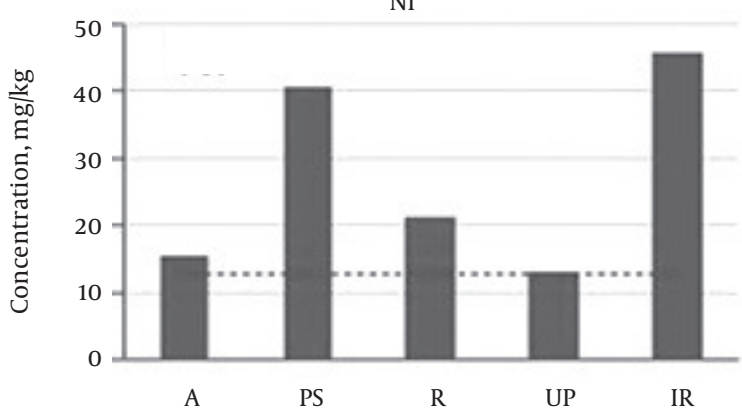

Zn

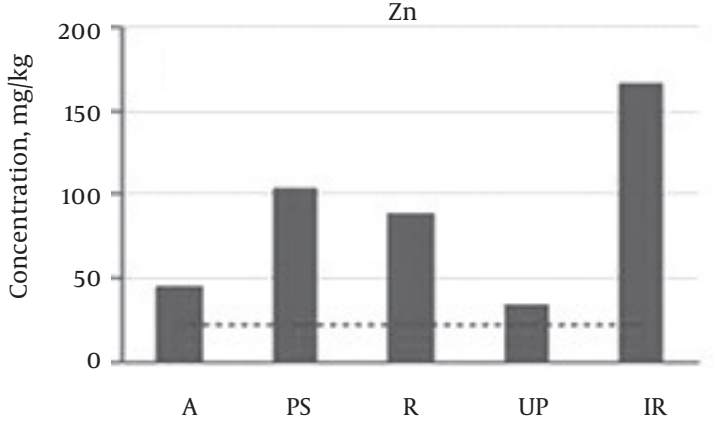

A, Agriculture; PS, public city square; R, residential area; UP, urban park; IR, industrial region. Horizontal lines represent the natural background.

lated by the fallowing equations respectively (Equations 2 and 3).

$E_{r}=T_{r} \times C_{f}$

PER $=\sum_{i}^{m} E_{r}$

In the above formula, $T_{r}$ is the toxic factor for each of the toxic metals (20). The amounts of $\mathrm{T}_{\mathrm{r}}$ were confirmed $30,5,5,5,2$ and 1 for $\mathrm{Cd}, \mathrm{Cu}, \mathrm{Pb}, \mathrm{Ni}, \mathrm{Cr}$ and $\mathrm{Zn}$, respectively (20).

The computed results of $\mathrm{E}_{\mathrm{r}}$ and PER for the investigated toxic metals in topsoil of Esfarayen are presented in Figure
2. The order of mean $\mathrm{E}_{\mathrm{r}}$ values were $\mathrm{Cd}>\mathrm{Cu}>\mathrm{Ni}>\mathrm{Pb}>\mathrm{Cr}$ $>$ Zn with mean $\mathrm{E}_{\mathrm{r}}$ values 109, 14.5, 12.7, 9.78, 8.35 and 4.55, respectively.

The amount of $\mathrm{E}_{\mathrm{ri}}$ for Cd was 109, which is considerably greater than that of other investigated metals. Results implied a significant ecological risk for $\mathrm{Cd}$ and a little potential ecological risk for $\mathrm{Cu}, \mathrm{Ni}, \mathrm{Pb}, \mathrm{Cr}$ and $\mathrm{Zn}$. This result was consistent with those of other studies (21). There was a difference between $\mathrm{E}_{\mathrm{r}}$ of $\mathrm{Cd}$ and those of other metals, which resulted from highly toxic factors of the abnormally high concentrations at most sites (21).The ecological risk factor of Cd was high $\left(E_{r}>80\right)$ for many evaluated sampling sites 


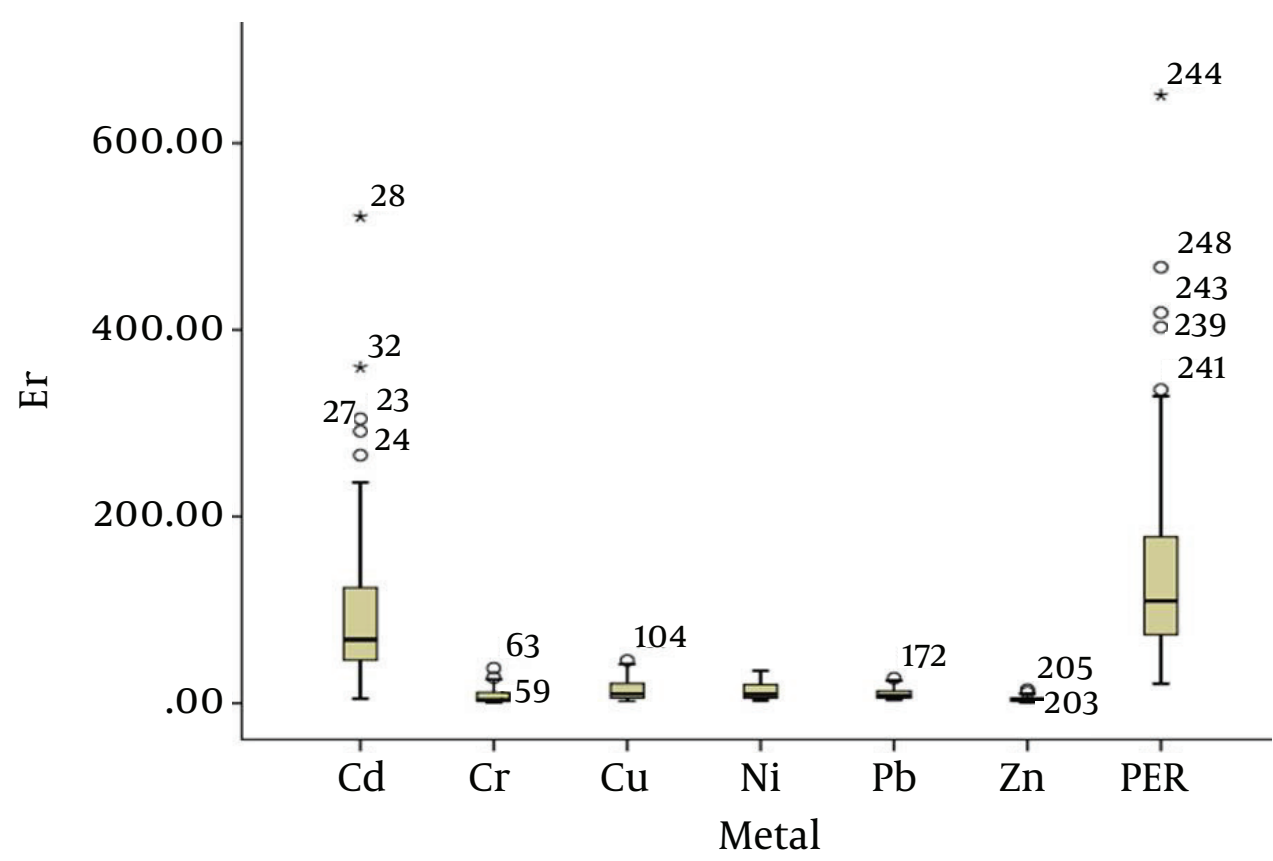

Figure 2. Boxplot of $E_{r}$ and PER of Heavy Metals in Soil Samples

(38.9\%). The results showed that Cd had high adverse effects on human community and live ecosystem. According to reported studies (1), Cd principally reveals the potential ecological risk of the environment. With comparison of land uses, the potential ecological risk factors were different $(\mathrm{P}<0.05)$ for various land uses (Figure 2 ).

The PER ranged from 20.88 to 651.28 with a mean value of 158.85, which indicated significant ecological risk for the investigated heavy metals in this area. According to the previous classifications, $16.67 \%$ of the samples were classified with a high potential ecological risk, $22.22 \%$ were classified with a considerable potential ecological risk, 36.11\% were considered to represent a moderate potential ecological risk, and $25 \%$ were classified as causing low potential ecological risk.

\section{Discussion}

The investigation of 40 soil samples from different functional areas in five districts of Esfarayen revealed a clear accumulation of $\mathrm{Cr}$ and $\mathrm{Zn}$. Among the functional areas the industrial regions and the city squares had the most serious metal contamination. Based on the results of the $C_{f}, E_{r}$ and PER, the investigated soils were moderately contaminated and had a considerable ecological risk on human community and live ecosystems in some sampling locations.

\section{Acknowledgments}

The authors would like to thank the North Khorasan University of Medical Sciences for the financial support of this study (No.93/p/764). Authors also wish to thank technical staff in the laboratory, Mr. Nazmara, for his cooperation.

\section{Footnote}

Authors' Contribution: Anoushiravan MohseniBandpei, Hossein Kamani, study design; Seyed Davoud Ashrafi and Ali Paseban, performing the experiments; Hossein Kamani and Ali Paseban, data analysis; Hossein Kamani and Ali Paseban, contributing reagents/materials/data analysis; Hossein Kamani and Ali Paseban, writing the manuscript. 
Table 2. A Summary of Heavy Metals Concentration in Various Cities of the World

\begin{tabular}{|c|c|c|c|c|c|c|c|}
\hline City & Cd & $\mathrm{Cr}$ & $\mathrm{Cu}$ & $\mathbf{N i}$ & $\mathbf{P b}$ & Zn & References \\
\hline Esfarayen, Iran & 0.21 & 33.27 & 39.9 & 32.3 & 25.2 & 106 & This study \\
\hline Tianjin, China & 0.18 & 45 & 33 & 33 & 48 & 136 & $(22)$ \\
\hline Beijing, China & 0.19 & 60 & 34 & 26 & 40 & 90 & (23) \\
\hline Nanjing, China & NA & 85 & 66 & NA & 107 & 163 & (24) \\
\hline Chongqing, China & 0.98 & 27 & 25 & 26 & 33 & 30 & $(25)$ \\
\hline Xi'an, China & NA & 81 & 54 & 35 & 60 & 186 & (26) \\
\hline Changsha, China & 6.9 & 121 & 51 & NA & 89 & 276 & $(27)$ \\
\hline Shenzhen, China & 0.47 & NA & 26 & NA & 47 & 69 & (28) \\
\hline Palermo, Italy & 0.68 & 34 & 63 & 18 & 202 & 138 & (29) \\
\hline Napoli, Italy & 0.58 & 15 & 94 & 12 & 204 & 223 & (30) \\
\hline Torino, Italy & NA & 191 & 90 & 209 & 149 & 183 & $(31)$ \\
\hline Seville, Spain & NA & 39 & 68 & 22 & 137 & 145 & (32) \\
\hline Mexico, Mexico & NA & 135 & 93 & 49 & 116 & 447 & (33) \\
\hline Tehran, Iran & 10.7 & 33.5 & 225 & 348 & 257 & 873 & (34) \\
\hline Istanbul Turkey & 2.3 & - & 209 & 33.3 & 212 & 521 & (35) \\
\hline Baoji China & - & 127 & 123 & 48.8 & 433 & 715 & (36) \\
\hline
\end{tabular}

Table 3. Indices and Grades of Potential Ecological Risk of Hazardous Elements Pollution

\begin{tabular}{|c|c|c|c|c|c|}
\hline $\mathrm{C}_{\mathrm{f}}$ & Description & $\mathbf{E}_{\mathbf{r}}$ & Description & PER & Description \\
\hline $\mathrm{C}_{\mathrm{f}}<\mathbf{1}$ & Low & $\mathrm{E}_{\mathrm{ri}}<40$ & Low risk & $\mathrm{PER}<65$ & Low risk \\
\hline $\mathbf{1} \leq \mathrm{C}_{\mathrm{f}}<\mathbf{3}$ & Moderate & $40 \leq \mathrm{E}_{\mathrm{ri}}<80$ & Moderate risk & $65 \leq \mathrm{PER}<130$ & Moderate risk \\
\hline $\mathbf{3} \leq \mathrm{C}_{\mathrm{f}}<\mathbf{6}$ & Considerable & $80 \leq \mathrm{E}_{\mathrm{ri}}<160$ & Considerable risk & $130 \leq \mathrm{PER}<260$ & Considerable risk \\
\hline \multirow[t]{2}{*}{$C_{f} \geq 6$} & High & $160 \leq \mathrm{E}_{\mathrm{ri}}<320$ & High risk & PER $>260$ & Very high risk \\
\hline & & $\mathrm{E}_{\mathrm{ri}} \geq 320$ & Very high risk & & \\
\hline
\end{tabular}

\section{References}

1. Luo XS, Yu S, Zhu YG, Li XD. Trace metal contamination in urban soils of China. Sci Total Environ. 2012;421-422:17-30. doi: 10.1016/j.scitotenv.2011.04.020. [PubMed: 21575982].

2. Kamani H, Ashrafi SD, Isazadeh S, Jaafari J, Hoseini M, Mostafapour FK, et al. Heavy metal contamination in street dusts with various land uses in Zahedan, Iran. Bull Environ Contam Toxicol. 2015;94(3):382-6. doi: 10.1007/s00128-014-1453-9. [PubMed: 25573278].

3. Naghipour D, Amouei A, Nazmara S. A comparative evaluation of heavy metals in the different breads in iran: A case study of rasht city. Health Scope. 2014;3(4).

4. Kamani H, Hoseini M, Safari GH, Jaafari J, Mahvi AH. Study of trace elements in wet atmospheric precipitation in Tehran, Iran. Environ Monit Assess. 2014;186(8):5059-67. doi: 10.1007/s10661-014-3759-9. [PubMed: 24718928].

5. Parizanganeh A, Zamani A, Bijnavand V, Taghilou B. Human nail usage as a Bio-indicator in contamination monitoring of heavy metals in Dizajabaad, Zanjan province-Iran. J Environ Health Sci Eng. 2014;12(1):147. doi:10.1186/s40201-014-0147-x. [PubMed: 25558375].

6. Kamani H, Hoseini M, Seyedsalehi M, Mahdavi Y, Jaafari J, Safari GH. Concentration and characterization of airborne particles in Tehran's subway system. Environ Sci Pollut Res Int. 2014;21(12):7319-28. doi 10.1007/s11356-014-2659-4. [PubMed: 24573466].

7. Solgi E, Khodabandelo H. Cadmium and lead disruption in soils around the hegmatan cement factory, Iran. Health Scope. 2016;5(2).

8. Ghaleno OR, Sayadi MH, Rezaei MR, Kumar CNP, Somashekar RK, Nagaraja BC. Potential ecological risk assessment of heavy metals in sediments of water reservoir case study: Chah Nimeh of Sistan. Proc Int Acad Ecol Environ Sci. 2015;5(4):89-96

9. Wei B, Yang L. A review of heavy metal contaminations in urban soils, urban road dusts and agricultural soils from China. Microchem J. 2010;94(2):99-107.

10. Morton-Bermea O, Hernández-Álvarez E, González-Hernández G, Romero F, Lozano R, Beramendi-Orosco LE. Assessment of heavy metal pollution in urban topsoils from the metropolitan area of Mexico City.J Geochemical Exploration. 2009;101(3):218-24.

11. USEPA. Soil screening guidance technical background document. Of fice of solid waste and emergency response; 1996.

12. VROM . Circular on Target Values and Intervention Values for Soil Remediation. 2000.

13. CCCoMot . Canadian soil quality guidelines for the protection of environmental and human health. Winnipeg; 2007. 
14. Wang X, Qin Y. Spatial distribution of metals in urban topsoils of Xuzhou (China): controlling factors and environmental implications. Environmental Geol. 2006;49(6):905-14.

15. Lu SG, Bai SQ. Study on the correlation of magnetic properties and heavy metals content in urban soils of Hangzhou City, China.J Applied Geophys. 2006;60(1):1-12.

16. Essumang DK, Dodoo DK, Obiri S, Oduro AK. Analysis of polycyclic aromatic hydrocarbons in street soil dust in Kumasi Metropolis of Ghana. Environ Monit Assess. 2006;121(1-3):401-8. doi: 10.1007/s10661005-9137-x. [PubMed: 16738775].

17. Duong TT, Lee BK. Determining contamination level of heavy metals in road dust from busy traffic areas with different characteristics. J Environ Manage. 2011;92(3):554-62. doi: 10.1016/j.jenvman.2010.09.010. [PubMed: 20937547].

18. Roubicek V, Raclavska H, Juchelkova D, Filip P. Wear and environmental aspects of composite materials for automotive braking industry Wear. 2008;265(1):167-75.

19. Sayadi MH, Shabani M, Ahmadpour N. Pollution index and ecological risk of heavy metals in the surface soils of amir-abad area in birjand city, Iran. Health Scope. 2015;4(1).

20. Hakanson L. An ecological risk index for aquatic pollution control. A sedimentological approach. Water Res. 1980;14(8):975-1001.

21. Suresh G, Sutharsan P, Ramasamy V, Venkatachalapathy R. Assessment of spatial distribution and potential ecological risk of the heavy metals in relation to granulometric contents of Veeranam lake sediments, India. Ecotoxicol Environ Saf. 2012;84:117-24. doi: 10.1016/j.ecoenv.2012.06.027. [PubMed: 22835728].

22. Zhao Q, Wang Y, Cao Y, Chen A, Ren M, Ge Y, et al. Potential health risks of heavy metals in cultivated topsoil and grain, including correlations with human primary liver, lung and gastric cancer, in Anhui province, Eastern China. Sci Total Environ. 2014;470-471:340-7. doi: 10.1016/j.scitotenv.2013.09.086. [PubMed: 24144938].

23. Xia X, Chen $X$, Liu R, Liu H. Heavy metals in urban soils with various types of land use in Beijing, China. J Hazardous Mater 2011;186(2):2043-50.

24. Lu Y, Gong Z, Zhang G, Burghardt W. Concentrations and chemical speciations of $\mathrm{Cu}, \mathrm{Zn}, \mathrm{Pb}$ and $\mathrm{Cr}$ of urban soils in Nanjing, China. Geoderma. 2003;115(1):101-11.

25. Li ZP, Chen YC, Yang XC, Wei SQ. Assessment of potential ecological hazard of heavy metals in urban soils in Chongqing City. J Southwest
Agri Univ Natur Sci (in Chinese). 2006;28(2):227-30

26. Chen X, Lu X, Yang G. Sources identification of heavy metals in urban topsoil from inside the Xi'an Second Ringroad, NW China using multivariate statistical methods. Catena. 2012;98:73-8.

27. Tao Z, Chaozhuang X, Tagen D, Danyan H. Comprehensive assessment of urban geological environment in changsha city [j]. Guangdong Trace Elements Sci. 2008;6:009.

28. Lu Y, Gan HH, Zhang BO, Shi ZJ. Concentration and chemical fractionation of heavy metals in soils of urban green space in Shenzhen City. Environ Chem. 2009;28(2):284-8.

29. Manta DS, Angelone M, Bellanca A, Neri R, Sprovieri M. Heavy metals in urban soils: a case study from the city of Palermo (Sicily), Italy. Sci Total Envi. 2002;300(1):229-43.

30. Cicchella D, De Vivo B, Lima A, Albanese S, McGill R, Parrish RR. Heavy metal pollution and $\mathrm{Pb}$ isotopes in urban soils of Napoli, Italy. Geochem: Explor, Envi, Analys. 2008;8(1):103-12.

31. Biasioli M, Barberis R, Ajmone-Marsan F. The influence of a large city on some soil properties and metals content. Sci Total Environ. 2006;356(1-3):154-64. doi: 10.1016/j.scitotenv.2005.04.033. [PubMed: 15941578].

32. Madrid L, Diaz-Barrientos E, Madrid F. Distribution of heavy metal contents of urban soils in parks of Seville. Chemosphere. 2002;49(10):1301-8. [PubMed: 12489727].

33. Rodriguez Martin JA, Arias ML, Grau Corbi JM. Heavy metals contents in agricultural topsoils in the Ebro basin (Spain). Application of the multivariate geoestatistical methods to study spatial variations. Environ Pollut. 2006;144(3):1001-12. doi: 10.1016/j.envpol.2006.01.045. [PubMed: 16580763].

34. Saeedi M, Li LY, Salmanzadeh M. Heavy metals and polycyclic aromatic hydrocarbons: pollution and ecological risk assessment in street dust of Tehran. J Hazard Mater. 2012;227-228:9-17. doi: 10.1016/j.jhazmat.2012.04.047. [PubMed: 22647232].

35. Sezgin N, Ozcan HK, Demir G, Nemlioglu S, Bayat C. Determination of heavy metal concentrations in street dusts in Istanbul E-5 highway. Environ Int. 2004;29(7):979-85. doi:10.1016/S0160-4120(03)000758. [PubMed: 14592575].

36. Lu X, Wang L, Lei K, Huang J, Zhai Y. Contamination assessment of copper, lead, zinc, manganese and nickel in street dust of Baoji, NW China. J Hazard Mater. 2009;161(2-3):1058-62. doi: 10.1016/j.jhazmat.2008.04.052. [PubMed:18502044]. 